\title{
Molecular Phylogenetic Analysis of Indonesian Fusarium Isolates from Different Lifestyles, based on ITS Sequence Data
}

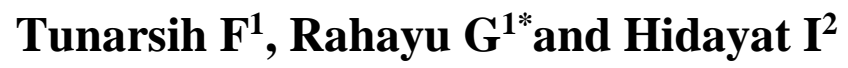 \\ ${ }^{1}$ Department of Biology, Faculty of Mathematics and Natural Sciences, Bogor Agricultural University, Darmaga \\ Campus, Bogor 16680, Indonesia \\ ${ }^{2}$ Research Center for Biology, Indonesian Institute of Sciences (LIPI), Cibinong 16911, Indonesia
}

Tunarsih F, Rahayu G, Hidayat I 2015 - Molecular Phylogenetic Analysis of Indonesian Fusarium isolates from different lifestyles, based on ITS sequence data. Plant Pathology \& Quarantine 5(2), 63-72, Doi 10.5943/ppq/5/2/5

\begin{abstract}
Fusarium species are pathogens, endophytes, and saprobes. Until recently, Fusarium species from Indonesia were mainly determined using morphology. In this study, molecular phylogenetic analysis of the Fusarium species complex in Indonesia, based on ITS rDNA sequence data, was carried out in order to analyze relationships among the Fusarium strains from different lifestyles. Strains isolated from plants, soil, litter, and other sources were used. Species belonging to six Fusarium species complexes, namely, F. oxysporum, F. solani, F. decemcellulare, $F$. graminearum, $F$. fujikuroi, and $F$. tricinctum were found. Fusarium oxysporum and $F$. solani are common species from Indonesia, found as saprobes, endophytes, and pathogens.
\end{abstract}

Key words - Fusarium diversity - identification - phylogenetic study

\section{Introduction}

Fusarium species are endophytes, saprobes, and pathogens to plants, animals, and humans. Plant pathogenic and endophytic fusaria have been reported associated with a wide range of plants (Summerbell \& Schroers 2002, Schroers et al. 2004, 2009). Pathogenic Fusarium species have also been recorded infecting several animals such as insects and nematodes (O'Donnell et al. 2012), while saprobic species are distributed in soil, humus, and decayed wood worldwide (Schroers et al. 2009, Silvestro et al. 2013).

The genus Fusarium was described by Link in 1809, and sanctioned by Fries in 1821 (Aoki et al. 2014). Similar to other fungal genera, the basic identification of Fusarium until end of 1980's was morphological based (Aoki et al. 2014). Taxonomy and identification of species belonging to Fusarium have been shifting from morphology based to molecular based approach (Baayen et al. 2001, Geiser et al. 2004, O'Donnell et al. 2008, 2012). It was due to rapid development in fungal DNA extraction and the polymerase chain reaction (PCR) techniques which allowed rapid molecular identification of many fungal genera, including Fusarium (Oechsler et al. 2009). It was predicted that about 300 phylogenetically distinct species of 
Fusarium would exist, based on the molecular phylogenetic approach, however, most of them have yet to be described (Aoki et al. 2014).

Among many gene regions, the internal transcribed spacer (ITS) region is considered as a universal genetic marker for fungi, and it has the highest probability of successful identification for fungi using molecular approach (Schoch et al. 2012). Evaluation of 18S rDNA gene, ITS1, 5.8S rDNA, 28S rDNA, $\beta$-tubulin gene, and aminoadipate reductase gene (lys 2 ) for inter-species identification of Fusarium showed that ratio of substitution rate of ITS1 regions is only lower than lys 2 gene and the percentages of inter-species nucleotide sequence homology ranged from 65- 100\% (Watanabe et al. 2011). This indicated that ITS region is still valuable in identification majority of Fusarium species, however, the ITS region provides low resolution in revealing Fusarium members within species complexes. Until a new gene region is determined as a suitable marker for the identification of fungi, in particular Fusarium, utilization of sequence from the ITS region for diversity studies is preferred.

In the last five years, identification and diversity studies of Fusarium in Indonesia has moved from morphology to molecular approach (Pinaria et al. 2010, Jumjunidang et al. 2012, Nugroho et al. 2013, Nurbaya et al. 2014). However, information regarding species diversity of Fusarium from these studies has been confusing and possibly inaccurate due to the molecular identification approach used in most studies from Indonesia, which heavily relied on BLAST search results, without knowing the reliability of the data for Fusarium sequences available at GenBank (http://www.ncbi.nlm.nih.gov). It was noted that about $20 \%$ of the fungal sequence entries in GenBank may be incorrectly identified (Nilsson et al. 2006), therefore, screening for the reliability of sequence data retrieved from GenBank and other fungal databases for molecular phylogenetic analysis is very important. It was recommended to use Fusarium-ID (http://isolate.fusariumdb.org/index.php) and Fusarium MLST (http://www.cbs.knaw.nl/ fusarium/) as sources of nucleotide sequences for molecular identification of Fusarium species (Aoki et al. 2014). In this study, diversity and phylogenetic relationship of Fusarium from Indonesia deposited at IPBCC (IPB Culture Collection) is elucidated using phylogenetic analysis based on nucleotide sequences generated from the ITS rDNA region.

\section{Materials \& Methods}

\section{Source of Fusarium isolates}

The information regarding Fusarium isolates in this study is shown in Table 1. All strains were obtained from Bogor Agricultural University Culture Collection (IPBCC), Bogor, Indonesia.

\section{DNA extraction, PCR amplification and sequencing}

Isolates were re-cultured in potato dextrose broth (PDB) (Difco, USA) for 5 days at room temperature on a rotary shaker. Mycelium was harvested, air-dried, and freeze-dried in liquid nitrogen, and total genomic DNA was extracted according to the SDS method (Raeder \& Broda $1985)$ with minor modification. In the PCR reaction, the primer set of ITS5 (forward) (5'GGAAGTAAAAGTCGTAACAAGG-3') and ITS4 (reverse) (5'-TCCTCCGCTTATTGATAT-3') (White et al. 1990) was used to amplify the ITS region including 5.8S rDNA. The 30 $\mu \mathrm{L}$ PCR mixture contained 1.2 $\mu \mathrm{L}$ DNA template, $3 \mu \mathrm{L}$ Dream Taq Buffer (including $\mathrm{MgCl}_{2}$ ) (Thermo Scientific, USA), $3 \mu \mathrm{L} 2 \mathrm{mM}$ dNTP (Thermo Scientific, USA), $0.6 \mu \mathrm{L}$ each $10 \mathrm{pmol}$ primer (ITS5 and ITS4) (Thermo Scientific, USA), $0.75 \mu \mathrm{L}$ Dream Taq polymerase (Thermo

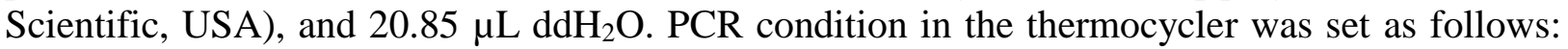
pre-denaturation at $94^{\circ} \mathrm{C}$ for $5 \mathrm{~min}, 30$ cycles of denaturation at $94^{\circ} \mathrm{C}$ for $30 \mathrm{~s}$, annealing at $52^{\circ} \mathrm{C}$ for $30 \mathrm{~s}$, extension at $72^{\circ} \mathrm{C}$ for $30 \mathrm{~s}$, and a final extension at $72^{\circ} \mathrm{C}$ for $7 \mathrm{~min}$. All PCR results were further visualized using UV transilluminator after electrophoresis through a $1 \%$ agarose gel and ethidium bromide staining. A 1-kb molecular weight ladder (Thermo Scientific, USA) was included in each run. PCR products were sent to $1{ }^{\text {st } B A S E ~(M a l a y s i a) ~ f o r ~ s e q u e n c i n g . ~}$ 
Table 1 List of 41 Fusarium strains studied, substrate or hosts, origin, lifestyle, and GenBank accession numbers.

\begin{tabular}{|c|c|c|c|c|c|c|}
\hline $\begin{array}{l}\text { Species } \\
\text { Complex }^{\#}\end{array}$ & Species & Source & Substrate/Host & Origin & Lifestyle & $\begin{array}{l}\text { GenBank } \\
\text { accession } \\
\text { number }\end{array}$ \\
\hline \multirow[t]{5}{*}{ FDSC } & F. decemcellulare & IPBCC 13.1101 & Solanum melongena & Bogor & Seed-borne & LC055813 \\
\hline & F. decemcellulare & IPBCC 14.1182 & S. melongena & Bogor & Seed-borne & KR610403 \\
\hline & F. decemcellulare & IPBCC 14.1183 & S. melongena & Bogor & Seed-borne & LC055814 \\
\hline & F. decemcellulare & IPBCC 14.1243 & S. melongena & Bogor & Seed-borne & KR610404 \\
\hline & F. decemcellulare & IPBCC 14.1244 & S. melongena & Bogor & Seed-borne & LC055820 \\
\hline \multirow[t]{2}{*}{ FFSC } & Fusarium sp. & IPBCC 08.580 & Litter of Shorea & Tarakan & Saprobe & KR610399 \\
\hline & Fusarium sp. & IPBCC 10.657 & Nest of insect & Pangandaran & Saprobe & KR610402 \\
\hline \multirow[t]{3}{*}{ FGSC } & F. cerealis & IPBCC 10.636 & Soil & Bogor & Saprobe & LC055809 \\
\hline & Fusarium sp. & IPBCC 07.526 & Agarwood of Aquilaria & West Papua & Endophyte & LC055793 \\
\hline & Fusarium sp. & IPBCC 11.881 & $\begin{array}{l}\text { Stem of Uncaria } \\
\text { gambier }\end{array}$ & West Sumatra & Endophyte & LC055812 \\
\hline \multirow[t]{16}{*}{ FOSC } & F. oxysporum & IPBCC 07.328 & Soil & Jambi & Saprobe & LC055790 \\
\hline & F. oxysporum & IPBCC 07.338 & Soil & Jambi & Saprobe & LC055791 \\
\hline & F. oxysporum & IPBCC 07.540 & Litter of Shorea & $\begin{array}{l}\text { Central } \\
\text { Kalimantan }\end{array}$ & Saprobe & LC055794 \\
\hline & F. oxysporum & IPBCC 08.561 & Agarwood of Aquilaria & Central Bangka & Endophyte & LC055796 \\
\hline & F. oxysporum & IPBCC 08.562 & Agarwood of Aquilaria & Central Bangka & Endophyte & LC055797 \\
\hline & F. oxysporum & IPBCC 08.565 & Agarwood of Aquilaria & Central Bangka & Endophyte & LC055800 \\
\hline & F. oxysporum & IPBCC 08.568 & Agarwood of Aquilaria & Sukabumi & Endophyte & LC055802 \\
\hline & F. oxysporum & IPBCC 08.582 & Litter of Shorea & Tarakan & Saprobe & KR610400 \\
\hline & F. oxysporum & IPBCC 10.656 & Nest of insect & Pangandaran & Saprobe & LC055810 \\
\hline & F. oxysporum & IPBCC 10.674 & Nest of insect & Pangandaran & Saprobe & LC055811 \\
\hline & F. oxysporum & IPBCC 14.1236 & Root of Cinchona & Bandung & Endopyhte & LC055815 \\
\hline & F. oxysporum & IPBCC 14.1237 & Root of Cinchona & Bandung & Endophyte & LC055816 \\
\hline & F. oxysporum & IPBCC 14.1238 & Root of Cinchona & Bandung & Endophyte & LC055817 \\
\hline & F. oxysporum & IPBCC 14.1239 & Root of Cinchona & Bandung & Endophyte & LC055818 \\
\hline & F. oxysporum & IPBCC 14.1242 & Root of Cinchona & Bandung & Endophyte & LC055819 \\
\hline & F. oxysporum & IPBCC 88.012 & Cucumis sativus & - & Pathogen & LC055821 \\
\hline \multirow[t]{13}{*}{ FSSC } & F. solani & IPBCC 07.525 & Agarwood of Aquilaria & Mataram & Endophyte & LC055792 \\
\hline & F. solani & IPBCC 08.560 & Agarwood of Aquilaria & Central Bangka & Endophyte & LC055795 \\
\hline & F. solani & IPBCC 08.564 & Agarwood of Aquilaria & Central Bangka & Endophyte & LC055799 \\
\hline & F. solani & IPBCC 08.566 & Stem of Aquilaria & Central Bangka & Endophyte & LC055801 \\
\hline & F. solani & IPBCC 08.569 & Stump of Aquilaria & Central Bangka & Endophyte & LC055803 \\
\hline & F. solani & IPBCC 08.570 & Stump of Aquilaria & Central Bangka & Endophyte & LC055804 \\
\hline & F. solani & IPBCC 08.571 & Stump of Aquilaria & Central Bangka & Endophyte & LC055805 \\
\hline & F. solani & IPBCC 08.574 & Litter of bushes & Tarakan & Saprobe & KR610398 \\
\hline & F. solani & IPBCC 08.602 & Litter of Shorea & Tarakan & Saprobe & LC055807 \\
\hline & Fusarium sp. & IPBCC 08.581 & Litter of Shorea & Tarakan & Saprobe & LC055806 \\
\hline & Fusarium sp. & IPBCC 08.563 & Agarwood of Aquilaria & Central Bangka & Endophyte & LC055798 \\
\hline & Fusarium sp. & IPBCC 08.612 & Soil & Tarakan & Saprobe & KR610401 \\
\hline & Fusarium sp. & IPBCC 88.014* & S. tuberosum & - & Pathogen & JX435207 \\
\hline \multirow{2}{*}{ FTSC } & Fusarium sp. & IPBCC 10.635 & Soil & Bogor & Saprobe & LC055808 \\
\hline & Fusarium sp. & IPBCC $88.017 *$ & - & - & - & LC055822 \\
\hline
\end{tabular}

- $\quad$ : unknown substrate/host, origin, or lifestyle.

* : Strain was obtained from CBS (Centraalbureau voor Schimmelcultures), Utrecht, the Netherlands.

\# $\quad$ : FDSC ( F. decemcellulare species complex), FFSC ( $F$. fujikuroi species complex), FGSC ( $F$. graminearum species complex), FOSC ( $F$. oxysporum species complex), FSSC ( $F$. solani species complex), FTSC ( $F$. tricinctum species complex) 


\section{Phylogenetic analysis}

DNA sequence generated from the ITS region was edited using ChromasPro version 1.7.7 (Technelysium, Australia). Multiple alignments were carried out in MEGA6 (Molecular Evolutionary Genetics Analysis Version 6.0) (Tamura et al. 2013) involving 41 nucleotide sequences from this study and sequences retrieved from GenBank (http://www.ncbi.nlm.nih.gov). The reliability of sequence data retrieved from GenBank was checked by comparing with data from Fusarium-ID (http://isolate.fusariumdb.org/index.php) and Fusarium MLST (http://www.cbs.knaw.nl/fusarium/). Sequence of Hypocrea lixii strain CBS 226.95 was used as outgroup (GenBank accession no. AF057606). The phylogenetic analysis was conducted using the maximum likelihood (ML) method in MEGA6. All parameter was set according to default program. The strength of the internal branches of the phylogenetic tree in ML analysis was tested with bootstrap (BS) analysis using 1000 replications. BS values of $50 \%$ or higher are shown.

\section{Results}

The alignment data matrix for ML analysis consisted of 89 sequences (including outgroup). Kimura-two parameter model with Gamma distribution was selected as the best DNA model of substitution in ML analysis for this dataset. The ITS tree showed that Fusarium sequences from this study belong to five distinct monophyletic clades represented species complexes, viz. F. graminearum species complex (FGSC) (BS=99\%), F. tricinctum species complex (FTSC) (BS=99\%), F. decemcellulare species complex (FDSC) (BS=100\%), F. solani species complex (FSSC) (BS=98\%), and $F$. oxysporum species complex (FOSC) (BS=60\%). Another clade, FFSC was determined here as polyphyletic (Fig. 1).

ITS can be used for determination of species within FDSC, FGSC, FOSC, and FSSC, but not in FFSC and FTSC (Table 1). Five strains, viz. IPBCC 13.1101, IPBCC 14.1182, IPBCC 14.1183, IPBCC 14.1243, and IPBCC 14.1244 are nested in FDSC and determined as $F$. decemcellulare. One (IPBCC 10.636) of the three strains nested in FGSC is determined as $F$. cerealis. Within FOSC, sixteen Fusarium strains are determined as $F$. oxysporum, viz. IPBCC 07.328, IPBCC 07.338, IPBCC 07.540, IPBCC 08.561, IPBCC 08.562, IPBCC 08.565, IPBCC 08.568, IPBCC 08.582, IPBCC 10.656, IPBCC 10.674, IPBCC 14.1236, IPBCC 14.1237, IPBCC 14.1238, IPBCC 14.1239, IPBCC 14.1242, and IPBCC 88.012. Nine Fusarium strains within FSSC are determined as $F$. solani, viz. IPBCC 07.525, IPBCC 08.560, IPBCC 08.564, IPBCC 08.566, IPBCC 08.569, IPBCC 08.570, IPBCC 08.571, IPBCC 08.574, and IPBCC 08.602 .

The tree also showed that Fusarium species with saprobe, endophyte, and pathogen lifestyles intermingled with each other in FGSC, FOSC, and FSSC clades (Fig. 1). Seed-borne Fusarium sequence from Solanum melongena nested in the same clade (FDSC), and additional sequences from seed-borne Fusarium are necessary to resolve whether this group of Fusarium is distinct from the Fusarium species with saprobe, endophyte, or pathogen lifestyle.

\section{Discussion}

Identifications of Fusarium in Indonesia using a molecular approach were reported by several authors in the last five years (Pinaria et al. 2010, Nugroho et al. 2013, Nurbaya et al. 2014), however, a phylogenetic study of the Fusarium species from Indonesia has not been carried out. This study showed the ITS rDNA sequence is still appropriate in determination of some Fusarium species, these include $F$. cerealis, $F$. decemcellulare, $F$. oxysporum, and $F$. solani. The ITS region offers a less complex tree, more efficient, low cost, and effective work (O'Donnell et al. 2008). Close related species such as $F$. verticillioides and $F$. proliferatum could also be differentiated based on sequence from the ITS region (Visentin et al. 2009). 
NR 121320 Fusarium asiaticum NRRL 26156

NR 121203 Fusarium boothii NRRL $29011 \mathrm{~T}$

NR 121204 Fusarium acaciae mearnsii NRRL 26754 T

LC055812 Fusarium sp IPBCC 11881 (endophyte)

LC055793 Fusarium sp IPBCC 07526 (endophyte)

67 LC055809 Fusarium cerealis IPBCC 10636 (saprobe)

99 AB820717 Fusarium cerealis MAFF 241212

AF006340 Fusarium cerealis NRRL 25491

HQ165936 Fusarium graminearum PUF033

AB587023 Fusarium langsethiae FRC T 1000

4 NR 121214 Fusarium langsethiae CBS 113234

AB587022 Fusarium langsethiae FRC T 0992

87 - AB587002 Fusarium acuminatum MAFF 236716

79 AB587026 Fusarium sporotrichioides CBS 119839

AB587025 Fusarium sporotrichioides ATCC 34914
AB587027 Fusarium sporotrichioides MAFF 236639

99 AB587019 Fusarium kyushuense MAFF 237645

AB587020 Fusarium kyushuense NRRL 6490 T

98,AB587024 Fusarium poae MAFF 305947

AB586983 Fusarium poae FRC T 0796

NR 120262 Fusarium bactridioides CBS $100057 \mathrm{~T}$

NR 120264 Fusarium guttiforme CBS 40997 T

KR610402 Fusarium sp IPBCC 10657 (saprobe)

U34570 Fusarium napiforme NRRL 13604

U34563 Fusarium pseudonygamai NRRL 13592 T

AB587010 Fusarium verticillioides CBS $57678 \mathrm{~T}$

KR610400 Fusarium oxysporum IPBCC 08582 (saprobe)

LC055819 Fusarium oxysporum IPBCC 141242 (endophyte)

LC055817 Fusarium oxysporum IPBCC 141238 (endophyte)

LC055816 Fusarium oxysporum IPBCC 141237 (endophyte)

LC055800 Fusarium oxysporum IPBCC 08565 (endophyte)

LC055794 Fusarium oxysporum IPBCC 07540 (saprobe)

LC055790 Fusarium oxysporum IPBCC 07328 (saprobe)

KF255448 Fusarium oxysporum CBS 133023 T

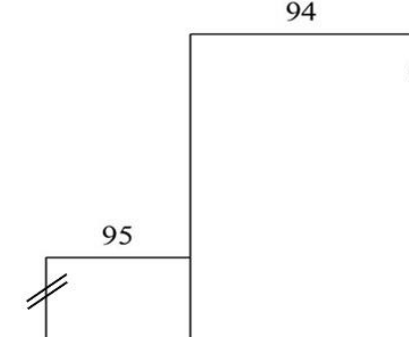

LC 055802 Fusarium oxysporum IPBCC 08568 (endophyte)

LC055791 Fusarium oxysporum IPBCC 07338 (saprobe)

LC055796 Fusarium oxysporum IPBCC 08561 (endophyte)

LC055797 Fusarium oxysporum IPBCC 08562 (endophyte)

LC055810 Fusarium oxysporum IPBCC 10656 (saprobe)

LC 055811 Fusarium oxysporum IPBCC 10674 (saprobe)

LC055815 Fusarium oxysporum IPBCC 141236 (endophyte)

LC055818 Fusarium oxysporum IPBCC 141239 (endophyte)

LC055821 Fusarium oxysporum IPBCC 88012 (pathogen)

FGSC

FFSC

FOSC 


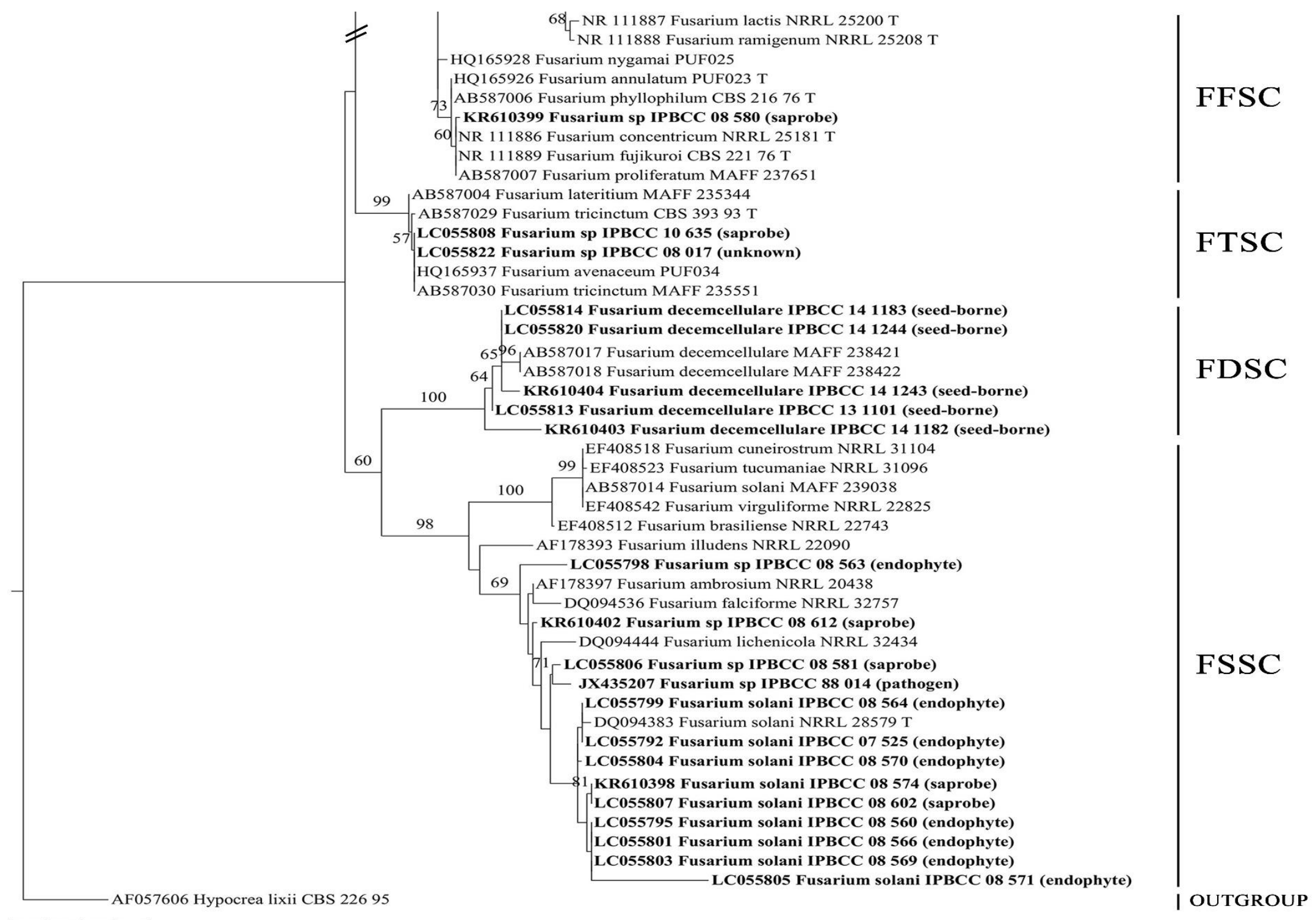

Fig. 1 - Maximum Likelihood phylogenetic tree for Fusarium species from Indonesia based on complete ITS ribosomal DNA sequence. Number over branches represents bootstrap support value from 1000 replicates $(\geq 50 \%)$. Bold characters represent strain used in this study. FDSC $(F$. decemcellulare species complex), FFSC ( $F$. fujikuroi species complex), FGSC ( $F$. graminearum species complex), FOSC ( $F$. oxysporum species complex), FSSC $(F$. solani species complex), FTSC (F. tricinctum species complex). 
However, this region is not sufficient to discriminate other members of $F$. fujikuroi complex such as $F$. verticillioides with $F$. subglutinans (O'Donnell \& Cigelnik 1997), or $F$. fujikuroi with $F$. proliferatum (Waalwijk et al. 1996). Least informative or low nucleotide sequence variation of the ITS region to clearly determine several species complex was also previously stated (Oechsler et al. 2009, Wang et al. 2011). This information suggested that researchers have to be careful during interpretation of the phylogenetic tree generated from ITS sequences (Cheng et al. 2008, O'Donnell et al. 2008).

This study showed that Fusarium sequences from different hosts or sources nested in the same species complex as shown in FOSC and FSSC clades. A wide host range in FOSC (Laurence et al. 2014) and FSSC (Suga et al. 2000) has been noted. The FOSC and FSSC are complex species which contain multiple morphologically cryptic species, and nucleotide sequence variation from the ITS region is not sufficient in differentiating the cryptic species within these species complexes. Genealogical Concordance Phylogenetic Species Recognition (GCPSR) concept using multigene approach from coding and non-coding region is considered best for the discrimination of species within FOSC and FSSC species complexes (Short et al. 2013, Laurence et al. 2014).

Species complexes in Fusarium may have different lifestyle. For example, the FOSC clade $(\mathrm{n}=16)$ composed of endophytic sequences from Aquilaria and Cinchona tree $(\mathrm{n}=9)$, pathogen of $C$. sativus $(\mathrm{n}=1)$, saprobes from plant litter, insect nest, and soil $(\mathrm{n}=6)$. The FSSC clade contains less diverse sources such as endophytes of Aquilaria $(n=8)$, pathogen from unknown source $(n=1)$, and saprobes in litter and soil $(n=4)$. The FGSC clade $(n=3)$ was also composed of endophytic $(n=2)$ and saprobic $(\mathrm{n}=1)$. In the FTSC clade, Fusarium strains $(\mathrm{n}=2)$ were saprobe and unknown source. Further, a single species of Fusarium may have different lifestyle as endophytes, pathogens, and saprobes. The spectrum of the Fusarium species complex may also differ in several respects. FOSC which is the most common species complex, has been reported to be saprobe, endophyte, and pathogen. Member of FOSC and FSSC have not been reported to be seed-borne, while all member of FDSC were seed-borne on S. melongena. Although most fusaria included in the present study have not been reported to cause infections in human and animal, some human pathogenic fusaria have been reported (Summerbell \& Schroers 2002, O'Donnell et al. 2008, Oechsler et al. 2009, Schroers et al. 2009, Wang et al. 2011). Fusarium coccophilum, which was recorded by O'Donnell et al. (2012) to associate with scale insect in Indonesia, has not been found in the present study.

Studies on molecular phylogenetic analysis of Fusarium species from several genetic loci have been done by many investigators, viz. $F$. redolens and $F$. hostae (mtSSU rDNA and EF-1 $\alpha$ ) (Baayen et al. 2001), F. oxysporum and $F$. commune (ITS, mtSSU, and EF-1 $\alpha$ ) (Stewart et al. 2006), FSSC and FTSC (ITS, LSU, EF-1 $\alpha$, and RPB2) (O'Donnell et al. 2008), FIESC and FCSC (EF-1 $\alpha$, RPB2, ITS+LSU, CAM) (O’Donnell et al. 2009), FDSC ( $\beta$-tub, ITS, LSU, and EF-1 $\alpha$ ) (Schroers et al. 2009), and FTSC, FIESC, FSAMSC, FOSC, GFSC, FSSC, FDSC (ITS, LSU, IGS, mtSSU, EF-1 $\alpha$, CAM, and RPB2) (Wang et al. 2011). Among the seven loci studied by Wang et al. (2011), the ITS, mtSSU, and LSU rRNA genes were least informative. For the identification of human pathogenic fusaria to species level, gene regions of EF-1 $\alpha$, RPB1, and RPB2 were suggested (O'Donnell et al. 2010). Recently, 22 species complexes were recognized for agriculture and medical Fusaria by using RPB1 and RPB2 (O'Donnell et al. 2013). To identify to at least the species complex level, EF-1 $\alpha$ was very capable to assign the strain due to high sequence similarity for the known Fusarium species in the Fusarium-ID database. Wang et al. (2011) suggested the IGS was the most informative locus to differentiate Fusarium strains, while RPB2 was less discriminatory than the IGS and the EF-1 $\alpha$ gene. Another gene region such as aminoadipate reductase gene (lys2) was also proposed as a suitable marker for the identification of Fusarium members (Watanabe et al. 2011, Watanabe 2013). In fact, each of proposed genes from Fusarium genome has possibly unique evolutionary history (Watanabe et al. 2011).

\section{Acknowledgements}

This research was supported by BOPTN DIPA IPB research grant awarded to Dr. Gayuh Rahayu. The authors also thank IPBCC for providing the Fusarium strains. 


\section{References}

Aoki T, O’Donnell K, Geiser DM. 2014 - Systematic of key phytopathogenic Fusarium species: current status and future challenges. Journal of General Plant Pathology 80, 189-201. Doi: 10.1007/s10327-014-0509-3.

Baayen RP, O’Donnell K, Breeuwsma S, Geiser DM, Waalwijk C. 2001 - Molecular relationships of fungi within the Fusarium redolens $-F$. hostae clade. Phytopathology 91, 1031-1044. Doi: 10.1094/PHYTO.2001.91.11.1037.

Cheng Z, Tang W, Su Z, Cai Y, Sun S, Chen Q, Wang F, Lin Y, She Z, Vrijmoed LLP. 2008 Identification of mangrove endophytic fungus 1403 (Fusarium proliferatum) based on morphological and molecular evidence. Journal of Forestry Research 19, 219-224. Doi: 10.1007/s11676-008-0030-7.

Geiser DM, Jime'nez-Gasco MM, Kang S, Makalowska I, Veeraraghavan N, Ward TJ, Zhang N, Kuldau GA, O'Donnell K. 2004 - FUSARIUM-ID v. 1.0: A DNA sequence database for identifying Fusarium. European Journal of Plant Pathology 110, 473-479. Doi: 10.1023/B:EJPP.0000032386.75915.a0.

Jumjunidang, Riska, Soemargono. 2012 - Identification and distribution of Fusarium oxysporum $\mathrm{f}$. sp. cubense isolates through analysis of vegetative compatibility group in Lampung Province, Indonesia. ARPN Journal of Agricultural and Biological Science 7, 279-284.

Laurence HM, Summerell BA, Burgess LW, Liew ECY. 2014 - Genealogical concordance phylogenetic species recognition in the Fusarium oxysporum species complex. Fungal Biology 118, 374-384. Doi: 10.1016/j.funbio.2014.02.002.

Nilsson RH, Ryberg M, Kristiansson E, Larsson KH, Kõljalg U. 2006 - Taxonomic reliability of DNA sequences in public sequences databases: a fungal perspective. PLoS ONE 1, e59. Doi: 10.1371/journal.pone.0000059.

Nugroho PA, Setyabudi FMCS, Saleh B, Rahayu ES. 2013 - Fumonisin-producing Fusarium from maize grains in Tretep, Indonesia. Journal of Food Science and Engineering 3, 534-540.

Nurbaya, Kuswinanti T, Rosmana A, Baharuddin, Millang S. 2014 - Growth rate and identification of Fusarium spp. associated with Aquillaria spp. from Nunukan regency, North Kalimantan. International Journal of Current Research and Academic Review 2, 33-40.

O’Donnell K, Cigelnik E. 1997 - Two divergent intragenomic rDNA ITS2 types within a monophyletic lineage of the fungus Fusarium are non-orthologous. Molecular Phylogenetics and Evolution 1, 1-14. Doi: 10.1006/mpev.1996.0376.

O’Donnell K, Sutton DA, Fothergill A, McCarthy D, Rinaldi MG, Brandt ME, Zhang N, Geiser DM. 2008 - Molecular phylogenetic diversity, multilocus haplotype nomenclature, and in vitro antifungal resistance within the Fusarium solani species complex. Journal of Clinical Microbiology 46, 2477-2490. Doi: 10.1128/JCM.02371-07.

O’Donnell K, Sutton DA, Rinaldi MG, Gueidan C, Crous PW, Geiser DM. 2009 - Novel multilocus sequence typing scheme reveals high genetic diversity of human pathogenic members of the Fusarium incarnatum-F. equiseti and $F$. chlamydosporum species complexes within the United States. Journal of Clinical Microbiology 47, 3851-3861. Doi:10.1128/JCM.01616-09.

O’Donnell K, Sutton DA, Rinaldi MG, Sarver BAJ, Balajee SA, Schroers HJ, Summerbell RC, Robert VA, Crous PW, Zhang N, Aoki T, Jung K, Park J, Lee YH, Kang S, Park B, Geiser DM. 2010 - Internet-accessible DNA sequence database for identifying fusaria from human and animal infections. Journal of Clinical Microbiology 48, 3708-3718. Doi: 10.1128/JCM.00989-10.

O’Donnell K, Humber RA, Geiser DM, Kang S, Crous PW, Johnston PR, Aoki T, Rooney AP, Rehner SA. 2012 - Phylogenetic diversity of insecticolous fusaria inferred from multilocus DNA sequence data and their molecular identification via FUSARIUM-ID and Fusarium MLST. Mycologia 104, 427-445. Doi: 10.3852/11-179. 
O’Donnell K, Rooney AP, Proctor RH, Brown DW, McCormick SP, Ward TJ, Frandsen RJN, Lysøe E, Rehner SA, Aoki T, Robert VARG, Crous PW, Groenewald JZ, Kang S, Geiser DM. 2013 - Phylogenetic analyses of RPB1 and RPB2 support a middle Cretaceous origin for a clade comprising all agriculturally and medically important fusaria. Fungal Genetics and Biology 52, 20-31. http://dx.doi.org/10.1016/j.fgb.2012.12.004

Oechsler RA, Feilmeier MR, Ledee DR, Miller D, Diaz MR, Fini ME, Fell JW, Alfonso EC. 2009 - Utility of molecular sequence analysis of the ITS rRNA region for identification of Fusarium spp. from ocular sources. Investigative Ophthalmology \& Visual Science 50, 2230-2236. Doi: 10.1167/iovs.08-2757.

Pinaria AG, Liew ECY, Burgess LW. 2010 - Fusarium species associated with vanilla stem rot in Indonesia. Australasian Plant Pathology 39, 176-183. Doi: 10.1071/AP09079.

Raeder U, Broda P. 1985 - Rapid preparation of DNA from filamentous fungi. Letters in Applied Microbiology 1, 17-20. Doi: 10.1111/j.1472-765X.1985.tb01479.x.

Schoch CL, Seifert K, Huhndorf S et al. 2012 - Nuclear ribosomal internal transcribed spacer (ITS) region as a universal DNA barcode marker for Fungi. Proceedings of the National Academy of Sciences of the United States of America 109, 6241-6246. Doi: 10.1073/pnas.1117018109.

Schroers HJ, Baayen RP, Meffert JP, Gruyter J, Hooftman M, O’Donnell K. 2004 - Fusarium foetens, a new species pathogenic to begonia elatior hybrids (Begonia $\times$ hiemalis) and the sister taxon of the Fusarium oxysporum species complex. Mycologia 96, 393-406. Doi: $10.2307 / 3762070$.

Schroers HJ, O’Donnell KO, Lamprecht SC, Kammeyer PL, Johnson S, Sutton DA, Rinaldi MG, Geiser DM, Summerbell RC. 2009 - Taxonomy and phylogeny of the Fusarium dimerum species group. Mycologia 101, 44-70. Doi: 10.3852/08-002.

Short DPG, O'Donnell K, Thrane U, Nielsen KF, Zhang N, Juba JH, Geiser DM. 2013 Phylogenetic relationships among members of the Fusarium solani species complex in human infections and the descriptions of $F$. keratoplasticum sp. nov. and $F$. petroliphilum stat. nov. Fungal Genetics and Biology 53, 59-70. Doi: 10.1016/j.fgb.2013.01.004.

Silvestro LB, Stenglein SA, Forjan H, Dinolfo MI, Arambarri AM, Manso L, Moreno MV. 2013 Occurrence and distribution of soil Fusarium species under wheat crop in zero tillage. Spanish Journal Agricultural Research 11, 72-79. Doi: 10.5424/sjar/2013111-3081.

Stewart JE, Kim MS, James RL, Dumroese RK, Klopfenstein NB. 2006 - Molecular characterization of Fusarium oxysporum and Fusarium commune isolates from a conifer nursery. Phytopathology 96, 1124-1133. Doi: 10.1094/PHYTO-96-1124.

Suga H, Hasegawa T, Mitsui H, Kageyama K, Hyakumachi M. 2000 - Phylogenetic analysis of the phytopathogenic fungus Fusarium solani based on the rDNA-ITS region. Mycological Research 104, 1175-1183. Doi: 10.1017/S0953756200002719.

Summerbell RC, Schroers HJ. 2002 - Analysis of phylogenetic relationship of Cylindrocarpon lichenicola and Acremonium falciforme to the Fusarium solani species complex and a review of similarities in the spectrum of opportunistic infections caused by these fungi. Journal of Clinical Microbiology 40, 2866-2875. Doi: 10.1128/JCM.40.8.2866-2875.2002.

Tamura K, Stecher G, Peterson D, Filipski A, Kumar S. 2013 - MEGA6: Molecular Evolutionary Genetics Analysis Version 6.0. Molecular Biology and Evolution 30, 27252729. Doi: 10.1093/molbev/mst197.

Visentin I, Tamietti G, Valentino D, Portis E, Karlovsky P, Moretti A, Cardinale F. 2009 - The ITS region as a taxonomic discriminator between Fusarium verticillioides and Fusarium proliferatum. Mycological Research 113, 1137-1145. Doi: 10.1016/j.mycres.2009.07.011.

Waalwijk C, De Koning JRA, Baayen RP, Bayen RP, Gams W. 1996 - Discordant grouping of Fusarium spp. from sections Elegans, Liseola, Dlaminia based on ribosomal ITS1 and ITS2 sequences. Mycologia 88, 361-368. Doi: 10.2307/3760877.

Wang H, Xiao M, Kong F, Chen S, Dou HT, Sorrell T, Li RY, Xu YC. 2011 - Accurate and practical identification of 20 Fusarium species by seven-locus sequence analysis and reverse 
line blot hybridization, and an in vitro antifungal susceptibility study. Journal of Clinical Microbiology 49, 1890-1898. Doi: 10.1128/JCM.02415-10.

Watanabe M. 2013 - Molecular phylogeny and identification of Fusarium species based on nucleotide sequences. Mycotoxins 63, 133-142. Doi: 10.2520/myco.63.133.

Watanabe M, Yonezawa T, Lee K, Kumagai S, Sugita-Konishi Y, Goto K, Hara-Kudo Y. 2011 Evaluation of genetic markers for identifying isolates of the species of the genus Fusarium. Journal of the Science of Food and Agriculture 91, 2500-2504. Doi: 10.1002/jsfa.4507.

White TJ, Bruns T, Lee S, Taylor J. 1990 - Amplification and direct sequencing of fungal ribosomal RNA genes for phylogenetics. In: PCR: A Guide to Methods and Applications. Edited by: Innis MA, Gelfand DH, Sninsky JJ, White TJ, Academic Press, New York, US, 315-322 pp. 